\title{
Isolation and Characterization of Actinophages Infecting Streptomyces Species and Their Interaction with Host Restriction-Modification Systems
}

\author{
By LUIS A. DIAZ, CARLOS HARDISSON AND M. ROSARIO RODICIO* \\ Departamento de Biología Funcional, Area de Microbiologia, Universidad de Oviedo, \\ 33006-Oviedo, Spain
}

(Received 4 January 1989; revised 3 April 1989; accepted 24 April 1989)

\begin{abstract}
Nine different phages, $\phi \mathrm{A} 1$ to $\phi \mathrm{A} 9$, were isolated from soil samples on Streptomyces antibioticus ATCC 11891, a strain which produces the macrolide antibiotic oleandomycin. Each phage displayed a different host-range which did not extend beyond Streptomyces species. Host-range was mainly limited by adsorption specificity and host-controlled restriction-modification systems. All the phages except $\phi \mathrm{A} 3$ and $\phi \mathrm{A} 9$ formed turbid plaques on $S$. antibioticus, but did not lysogenize this host. However, three of the phages $(\phi \mathrm{A} 5, \phi \mathrm{A} 7$ and $\phi \mathrm{A} 8)$ were identified as temperate, since they were able to lysogenize other Streptomyces strains. All of the phages were morphologically similar and belonged to group B of Bradley's classification. They had polyhedral heads and long, non-contractile tails. $\phi \mathrm{A} 5, \phi \mathrm{A} 6$ and $\phi \mathrm{A} 7 \mathrm{had}$ a base plate at the terminal end of the tail. Analysis with restriction endonucleases indicated that the nine phages contained double-stranded DNA. Hybridization studies between the phage genomes, together with results on genome structure, allowed classification of the phages into five groups: (I) $\phi \mathrm{A} 2, \phi \mathrm{A} 4$ and $\phi \mathrm{A} 9$, (II) $\phi \mathrm{A} 3$ and $\phi \mathrm{A} 8$, (III) $\phi \mathrm{A} 7$, (IV) $\phi \mathrm{A} 5$ and $\phi \mathrm{A} 6$, and (V) $\phi \mathrm{A} 1$.
\end{abstract}

\section{INTRODUCTION}

Streptomyces phages are of interest for a variety of reasons, including (1) the problems they cause in fermentation industries, (2) their value for typing streptomycetes in taxonomic studies (Bradley et al., 1961; Korn et al., 1978), (3) their use for the detection and understanding of hostcontrolled restriction-modification systems, (4) their utilization as tools for genetic exchange and analysis in Streptomyces, and (5) the study of their general and molecular biology (for reviews on 3, 4 and 5 see Lomovskaya et al., 1980; Chater, 1986).

Several temperate actinophages ( $\phi$ C 31, R4, SH10, TGI, $\phi$ SFI; see Chater, 1986) have been developed into cloning vectors, as alternatives to plasmids in the genetic manipulation of Streptomyces species. $\phi \mathrm{C} 31$ is the best characterized and has been used successfully for the cloning and functional analysis of Streptomyces DNA (Chater et al., 1985). Although $\phi \mathrm{C} 31$ shows a broad host-range, including about half of the 137 strains on which it has been tested (Voeykova et al., 1979; Chater, 1986), it does not infect $S$. antibioticus ATCC 11891, a strain which produces the macrolide antibiotic oleandomycin. In this paper we report the isolation from soil of nine new phages able to form plaques on this strain and their preliminary characterization. We have analysed the interaction of these phages with other strains of Streptomyces, some of which produce well-characterized restriction-modification systems, and have assessed their potential for development into cloning vectors.

\section{METHODS}

Bacteria, phages and their propagation. Streptomyces and other actinomycete strains used in this work are listed in Table 3. Phages $\phi$ C31 (Lomovskaya et al., 1972) and R4 (Chater \& Carter, 1979) were kindly provided by K. F. Chater (John Innes Institute, Norwich, UK), and SH10 (Klaus et al., 1981) by S. Klaus (Zentralinstitut für Mikrobiologie und Experimentelle Therapie, Jena, DDR). Other phages were isolated from soil as described 
below. General bacterial and phage techniques were as in Hopwood et al. (1985) but R2YE medium (Thompson $e t$ al., 1980) was only used for culture of $S$. lividans 1326 and $S$. coelicolor. All other strains were grown and sporulated on GAE (Hardisson et al., 1978).

Phage isolation. Phages infecting S. antibioticus ATCC 11891 were isolated from soil following essentially the enrichment method of Dowding (1973). Samples ( $1 \mathrm{~g}$ ) of commercially available garden soil (of unknown origin and characteristics) were added to nutrient broth $(10 \mathrm{ml})$ supplemented with glucose $(1 \%, \mathrm{w} / \mathrm{v}), \mathrm{MgSO}_{4}(10 \mathrm{mM})$, $\mathrm{Ca}\left(\mathrm{NO}_{3}\right)_{2}(8 \mathrm{mM})$, oleandomycin $\left(50 \mu \mathrm{g} \mathrm{ml}^{-1}\right)$ and spores (about $\left.10^{6}\right)$ of $S$. antibioticus. After overnight incubation at $30^{\circ} \mathrm{C}$ with shaking, samples were centrifuged and supernatants were sterilized by passage through Millipore filters $(0.45 \mu \mathrm{m})$. Phages were detected by plating in soft agar overlays (Hopwood et al., 1985), using S. antibioticus as indicator strain. Phages were distinguished by differences in plaque morphology, size and turbidity, and were purified by serial replating from single plaques.

Morphological studies. Phage particles from high-titre lysates were stained with $2 \%(w / v)$ potassium phosphotungstate, pH 7, and observed under a Zeiss EM109 electron microscope, as decribed by Suárez et al. (1984).

Preparation and in vitro manipulation of phage DNA. Phage DNA was extracted from high-titre lysates by hotSDS disruption of the particles, as described by Suárez \& Chater (1981). Standard procedures (Hopwood et al., 1985) were used for restriction enzyme digestions, ligation and agarose gel electrophoresis. Cohesive ends were detected by comparison of the gel patterns corresponding to unheated and heated $\left(70^{\circ} \mathrm{C}, 10 \mathrm{~min}\right)$, or to ligated and unligated, phage DNA, digested with appropriate restriction enzymes. Homology between phage genomes was investigated by Southern hybridization. Digested phage DNAs were electrophoresed, transferred to nitrocellulose filters and probed with ${ }^{35} \mathrm{~S}$ - or ${ }^{32} \mathrm{P}$-labelled phage DNA. Hybridization and washing of Southern blots was done in conditions which would allow detection of DNA sequences of about 500 bp with $>84 \%$ base sequence identity to the probe (Hopwood et al., 1985; hybridization procedure 'B').

Host-range determinations. Plaque formation by serial dilutions of each phage was used rather than qualitative spot tests (which frequently gave false positive results) to determine the host range of the phages.

Identification of temperate phages and determination of immunity. Phages $(5-10 \mu 1$ of a suspension containing about $10^{6}$ p.f.u. $\mathrm{ml}^{-1}$ ) were spotted on GAE (Hardisson et al., 1978) plates inoculated with spores of the appropriate strain. Plates were incubated at $30^{\circ} \mathrm{C}$ until cells growing within the lysis zone sporulated. Spores were transferred into $1 \mathrm{ml}$ of $0.1 \mathrm{M}$-tetrasodium pyrophosphate and left at $37^{\circ} \mathrm{C}$ for $30 \mathrm{~min}$. Then they were filtered through a $0.45 \mu \mathrm{m}$ filter, washed three times with $5 \mathrm{ml}$ tetrasodium pyrophosphate and finally resuspended in $1 \mathrm{ml}$ sterile distilled water. Spores were serially diluted and spread on GAE plates. After sporulation they were replicated to lawns of an appropriate indicator strain and tested for the liberation of phage. Spores prepared from phage-producing colonies were checked for resistance against superinfection by the same phage using the aforementioned soft agar overlay method. Putative lysogens for one phage were also subjected to infection by other lysogenic phages in order to establish immunity relationships.

\section{RESULTS AND DISCUSSION}

\section{Isolation of phages infecting $S$. antibioticus}

Phage plaques were obtained on S. antibioticus ATCC 11891 from different garden soil samples, enriched by pre-incubation with the host in the presence of oleandomycin. Using differences in plaque morphology, size and degree of turbidity as initial criteria, nine different phages, termed $\phi \mathrm{A} 1$ to $\phi \mathrm{A} 9$, were identified. $\phi \mathrm{A} 3$ and $\phi \mathrm{A} 9$ produced clear plaques on lawns of $S$. antibioticus. All the other phages formed turbid plaques. The uniqueness of each phage was confirmed by morphological studies of the phage particles, analysis of the genome and hostrange determination.

\section{Morphology of the virions}

Electron microscope observations (Fig. 1) showed that the nine phages had polyhedral heads and long, apparently non-contractile tails (like nearly all previously characterized Streptomyces phages). Phages $\phi \mathrm{A} 5, \phi \mathrm{A} 6$ and $\phi \mathrm{A} 7 \mathrm{had}$ a baseplate at the end of the tail. The dimensions of the phages are shown in Table 1 . The largest phage, $\phi \mathrm{Al}$, had a head of $79 \mathrm{~nm}$ from apex to apex and a tail $327 \mathrm{~nm}$ long. The heads of the other phages ranged from 50 to $62 \mathrm{~nm}$ but the length of the tails showed a greater variation $(100$ to $230 \mathrm{~nm})$.

\section{Characterization of phage genomes}

The genomes of all the phages consisted of double-stranded DNA, as deduced from analysis with restriction endonucleases. This is also the case for all other actinophages reported so far and 

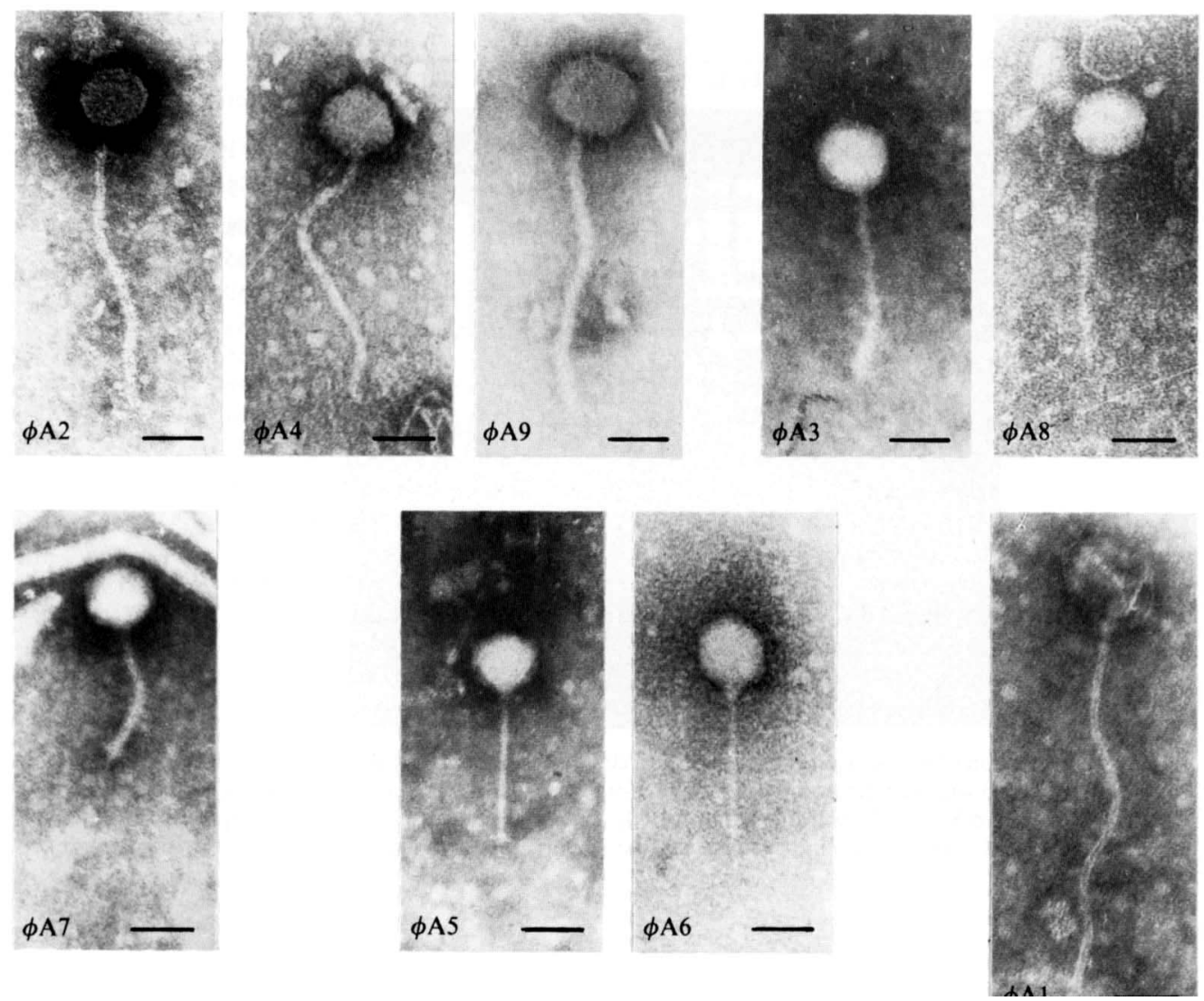

Fig. 1. Electron micrographs of Streptomyces phages. (Note that the phages are grouped by similarity.) Bars, $50 \mathrm{~nm}$.

Table 1. Phage dimensions

\begin{tabular}{|c|c|c|c|c|c|}
\hline \multirow[b]{2}{*}{ Phage } & \multicolumn{2}{|c|}{ Head $^{*}$} & \multicolumn{2}{|c|}{ Tail $^{*}$} & \multirow[b]{2}{*}{ Base-plate $\dagger$} \\
\hline & Apex to apex & Side to side & Length & Width & \\
\hline $\begin{array}{l}\phi \mathrm{A} 2 \\
\phi \mathrm{A} 4 \\
\phi \mathrm{A} 9\end{array}$ & $\begin{array}{l}52 \pm 3 \\
61 \pm 3 \\
62 \pm 4\end{array}$ & $\begin{array}{l}48 \pm 3 \\
58 \pm 3 \\
59 \pm 4\end{array}$ & $\begin{array}{l}228 \pm 12 \\
233 \pm 8 \\
227 \pm 6\end{array}$ & $\begin{array}{l}8 \\
7 \\
8\end{array}$ & $\begin{array}{l}- \\
- \\
-\end{array}$ \\
\hline $\begin{array}{l}\phi \mathrm{A} 3 \\
\phi \mathrm{A} 8\end{array}$ & $\begin{array}{l}55 \pm 3 \\
56 \pm 4\end{array}$ & $\begin{array}{l}53 \pm 3 \\
50 \pm 3\end{array}$ & $\begin{array}{l}150 \pm 9 \\
145 \pm 8\end{array}$ & $\begin{array}{l}7 \\
7\end{array}$ & $\begin{array}{l}- \\
-\end{array}$ \\
\hline$\phi \mathrm{A} 7$ & $52 \pm 3$ & $48 \pm 4$ & $102 \pm 5$ & 7 & + \\
\hline $\begin{array}{l}\phi \mathrm{A} 5 \\
\phi \mathrm{A} 6\end{array}$ & $\begin{array}{l}50 \pm 2 \\
57 \pm 3\end{array}$ & $\begin{array}{l}46 \pm 3 \\
51 \pm 3\end{array}$ & $\begin{array}{l}110 \pm 3 \\
115 \pm 3\end{array}$ & $\begin{array}{l}6 \\
6\end{array}$ & $\begin{array}{l}+ \\
+\end{array}$ \\
\hline$\phi \mathrm{Al}$ & $79 \pm 6$ & $73 \pm 5$ & $327 \pm 35$ & 9 & - \\
\hline
\end{tabular}

* Values are given in $\mathrm{nm}$, and are means \pm SD of at least 10 independent measurements. $\dagger+$, presence, - , absence of basal plate.

for all bacteriophages with complex symmetry. The number and size of fragments obtained after digestion with each of 20 restriction enzymes (Table 2) confirmed the uniqueness of each phage. The phages were also distinct from $\phi \mathrm{C} 31$ (Harris et al., 1983), R4 (Morino et al., 1983), SH10 (Walter et al., 1981), TG1 (Foor et al., 1985) and other reported actinophages. 


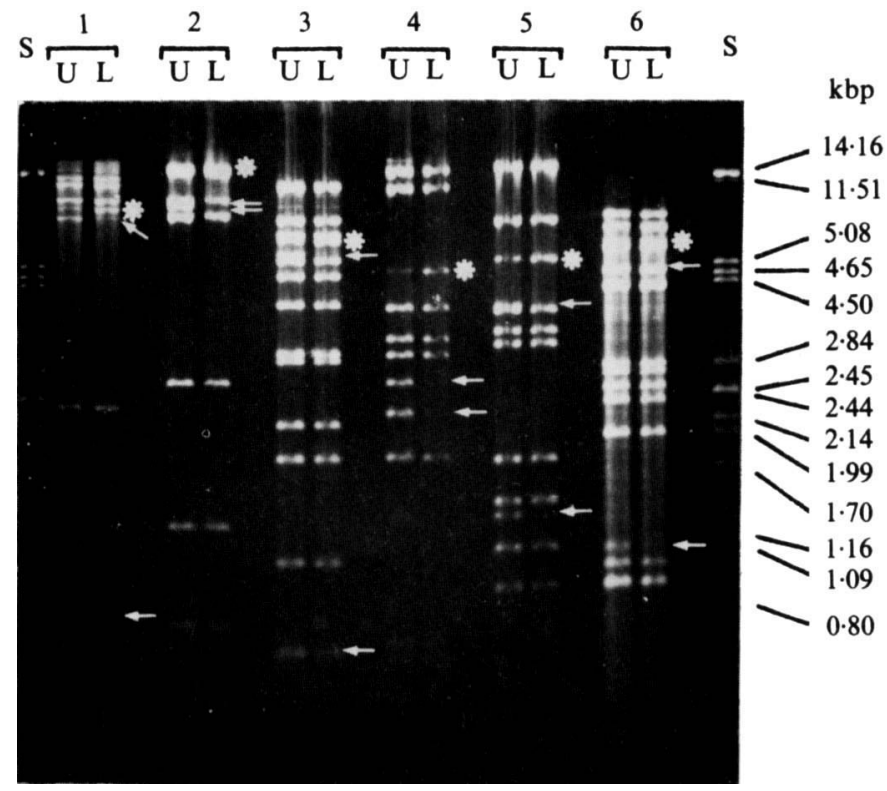

Fig. 2. Detection of cohesive ends by agarose gel electrophoresis of ligated $(\mathrm{L})$ and unligated $(\mathrm{U})$ phage DNAs, digested with restriction enzymes. S, Pst l-digested $\lambda$ (size standards); 1, EcoRI-digested $\phi$ A2 $; 2$, $B g l$ II-digested $\phi$ A3; 3, EcoRI-digested $\phi$ A4; 4, EcoRV-digested $\phi$ A7; 5, BglII-digested $\phi$ A8; 6, $B s t$ EII-digested $\phi \mathrm{A} 9$. Arrows indicate the fragments carrying the cohesive ends and asterisks the cos fragment.

Table 2. Restriction enzyme analysis of phage DNA

\begin{tabular}{lccccccccc} 
Restriction & \multicolumn{7}{c}{ Number of fragments obtained after digestion } \\
endonuclease & $\phi \mathrm{A} 2$ & $\phi \mathrm{A} 4$ & $\phi \mathrm{A} 9$ & $\phi \mathrm{A} 3$ & $\phi \mathrm{A} 8$ & $\phi \mathrm{A} 7$ & $\phi \mathrm{A} 5$ & $\phi \mathrm{A} 6$ & $\phi \mathrm{A} 1$ \\
AvaI & $\geqslant 15$ & $\geqslant 15$ & $\geqslant 15$ & $\geqslant 15$ & $\geqslant 15$ & $\geqslant 15$ & $\geqslant 15$ & $\geqslant 20$ & $\geqslant 15$ \\
BamHI & - & $\geqslant 15$ & $\geqslant 15$ & - & - & - & - & - & - \\
BclI & $\geqslant 15$ & $\geqslant 15$ & $\geqslant 15$ & $\geqslant 10$ & 12 & 12 & 6 & $\geqslant 10$ & - \\
BglI & $\geqslant 15$ & $\geqslant 15$ & $\geqslant 15$ & $\geqslant 15$ & $\geqslant 15$ & $\geqslant 15$ & $\geqslant 10$ & $\geqslant 10$ & $\geqslant 15$ \\
BglII & 10 & $\geqslant 10$ & $\geqslant 15$ & 7 & 11 & - & 3 & - & $\geqslant 15$ \\
BstEII & 8 & $\geqslant 10$ & $\geqslant 10$ & $\geqslant 15$ & $\geqslant 15$ & $\geqslant 20$ & $\geqslant 10$ & 7 & $\geqslant 15$ \\
ClaI & 11 & $\geqslant 10$ & $\geqslant 10$ & 2 & 3 & 5 & - & 3 & $\geqslant 10$ \\
EcoRI & 6 & 13 & 12 & 3 & 3 & 8 & 4 & 2 & $\geqslant 15$ \\
EcoRV & 3 & 8 & 9 & - & - & 11 & 5 & 5 & $\geqslant 15$ \\
HindII & NT & NT & NT & NT & $\geqslant 10$ & $\geqslant 10$ & - & NT & NT \\
HindIII & - & $\geqslant 10$ & 9 & - & 2 & - & - & - & $\geqslant 15$ \\
HpaI & 6 & - & - & - & - & 3 & - & - & $\geqslant 15$ \\
KpnI & $\geqslant 10$ & 9 & P & 7 & P & P & 8 & P & $\geqslant 15$ \\
PstI & $\geqslant 10$ & $\geqslant 10$ & $\geqslant 15$ & - & - & - & - & - & - \\
PvuI & $\geqslant 10$ & $\geqslant 15$ & $\geqslant 15$ & - & - & 7 & $\geqslant 10$ & $\geqslant 15$ & - \\
PvuII & $\geqslant 10$ & $\geqslant 10$ & $\geqslant 10$ & - & - & - & - & $\geqslant 15$ & - \\
SacI & $\geqslant 10$ & $\geqslant 20$ & $\geqslant 15$ & $\geqslant 15$ & $\geqslant 15$ & - & - & - & - \\
SacII & $\geqslant 15$ & $\geqslant 15$ & $\geqslant 15$ & - & - & 2 & $\geqslant 10$ & $\geqslant 10$ & - \\
SalGI & $\geqslant 10$ & $\geqslant 15$ & $\geqslant 15$ & P & $\geqslant 10$ & - & $\geqslant 10$ & $\geqslant 15$ & 3 \\
SmaI & NT & NT & NT & NT & - & - & $\geqslant 10$ & NT & NT \\
XbaI & 2 & 3 & 3 & - & - & 7 & - & - & P \\
XhoI & - & - & $\geqslant 10$ & - & - & - & - & - & - \\
XhoII & NT & NT & NT & NT & $\geqslant 15$ & $\geqslant 10$ & - & NT & NT
\end{tabular}

-, No cleavage sites; NT, not tested; P, partial digest. 

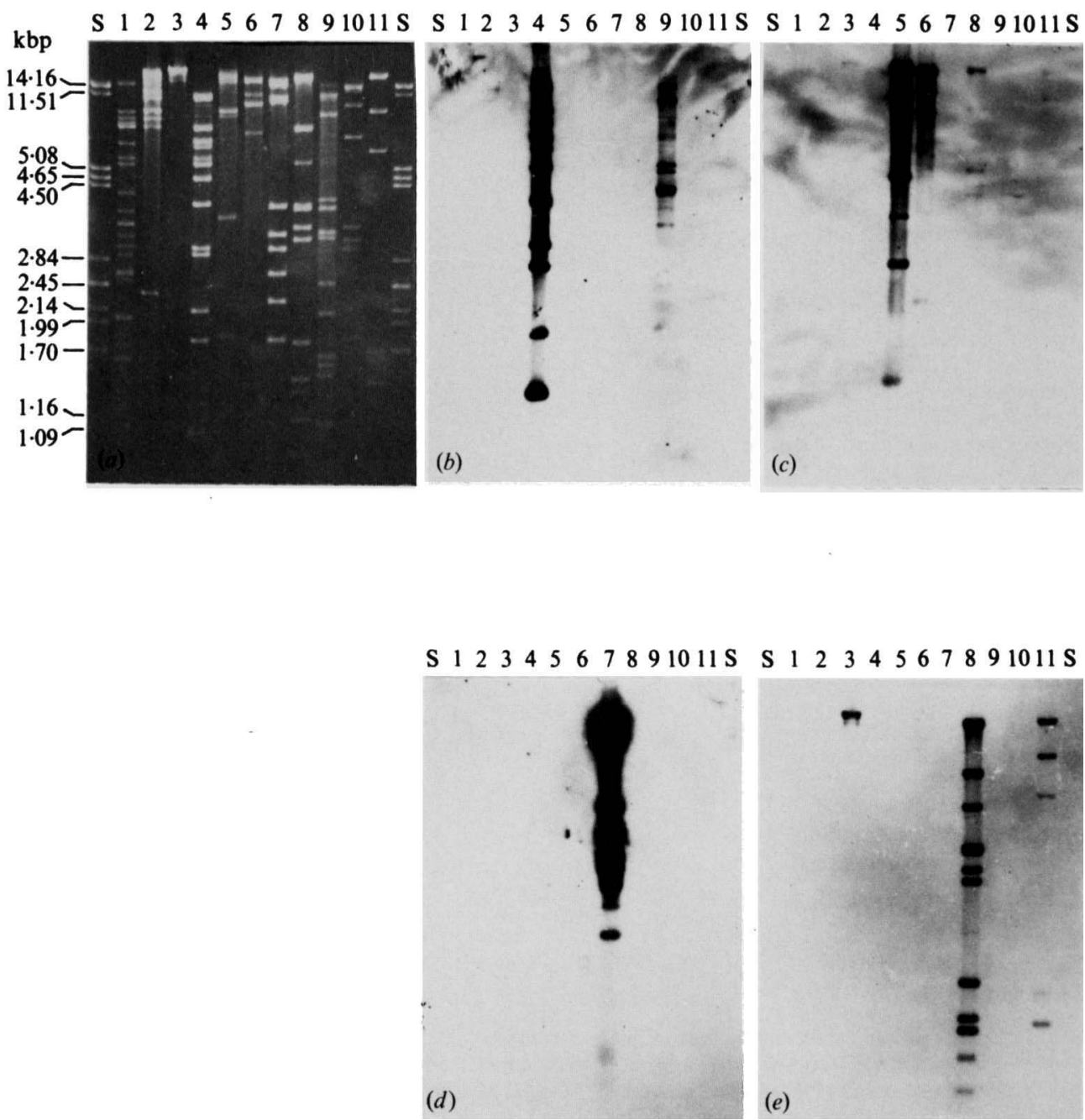

Fig. 3. Hybridization between phage DNAs. (a) Restriction enzyme digests of different phage DNAs. Lanes: S, PstI-digested $\lambda$ (size standards); 1, EcoR V-digested $\phi \mathrm{A} 1 ; 2, E c o R I$-digested $\phi \mathrm{A} 2 ; 3$, EcoRIdigested $\phi \mathrm{A} 3 ; 4$, EcoRI-digested $\phi \mathrm{A} 4 ; 5, E c o \mathrm{RV}$-digested $\phi \mathrm{A} 5 ; 6, E c o \mathrm{RV}$-digested $\phi \mathrm{A} 6 ; 7, E c o \mathrm{RV}$ digested $\phi \mathrm{A} 7,8, B g l$ II-digested $\phi \mathrm{A} 8 ; 9, E c o$ RI-digested $\phi \mathrm{A} 9 ; 10, E c o$ RI-digested $\phi \mathrm{C} 31 ; 11, B g l \mathrm{II}$ digested SH10. $(b, c, d, e)$ Southern blots of gels similar to the one shown in $(a)$, probed with $(b){ }^{35} \mathrm{~S}-$ labelled $\phi$ A4 DNA, $(c){ }^{35}$ S-labelled $\phi$ A5 DNA, $(d){ }^{32}$ P-labelled $\phi$ A7 DNA, and $(e){ }^{35}$-labelled $\phi$ A8 DNA.

By summation of restriction fragments for each of several endonucleases, the lengths of the double-stranded DNA molecules were calculated for $\phi \mathrm{A} 1$ (100 kbp), $\phi \mathrm{A} 2$ (43 kbp), $\phi \mathrm{A} 3$ (51 kbp), $\phi \mathrm{A} 4$ (49 kbp), $\phi \mathrm{A} 7$ (46 kbp), $\phi \mathrm{A} 8(50 \mathrm{kbp})$ and $\phi \mathrm{A} 9(53 \mathrm{kbp})$. All of these except $\phi \mathrm{A} 1$ had cohesive ends (Fig. 2), as commonly found among Streptomyces phages.

In the cases of $\phi \mathrm{A} 5$ and $\phi \mathrm{A} 6$, disagreements in the length of the genome obtained from different enzyme digests were observed, and sub-stoichiometric bands were always present in gels. Such bands were not due to partial digestions and they did not correspond to fused and unfused cohesive ends. These observations could be explained by the occurrence in the population of heterogeneous phage molecules present as a result of packaging of the DNA by the headful mechanism (Botstein et al., 1973; Jackson et al., 1978; Sternberg \& Hoess, 1983). 
Table 3. Bacteriophage plaque formation on Streptomyces and other actinomycetes

None of the bacteriophages formed plaques on Saccharopolyspora erythraea NRRL B-2338, Micromonospora chalcea ATCC 12452, M. purpurea ATCC 15835, Micromonospora sp. IMET 8002 or Nocardia mediterranea ATCC 13685.

Strain*

Streptomyces antibioticus ATCC 11891

S. antibioticus CECT 3224

S. antibioticus CECT 3225

S. antibioticus CECT 3232

S. antibioticus CECT 3234

S. antibioticus ETHZ 7451

S. antibioticus KCC S-0680

S. antibioticus KCC S-0707

S. antibioticus KCC S-0868

S. achromogenes ATCC 12767

S. albus $\mathrm{G} \dagger$

S. albus $\mathrm{J} 1074$

S. albus $\mathrm{P}$ (CMI 52766)

S. clavuligerus ATCC 27064

S. coelicolor CECT 3079

S. coelicolor $\mathrm{J} 1501$

S. fradiae NRRL B-3357

S. glaucescens CECT 3175

S. glaucescens ETHZ 22794

S. griseus ATCC 11429

S. hygroscopicus UC 5208

S. lavendulae NRRL B-1871

$S$. lavendulae NRRL B-2036

S. lavendulae NRRL B-2343

S. lividans ATCC 19844

S. lividans 66 (JII strain 1326)

S. lydicus UC 2056

S. orchidaceus NRRL B-2454

S. scabies CMI 99049

S. showdoensis Z-452

S. spectabilis UC 2472

$\begin{array}{lllllllll}\phi \mathrm{A} 2 & \phi \mathrm{A} 4 & \phi \mathrm{A} 9 & \phi \mathrm{A} 3 & \phi \mathrm{A} 8 & \phi \mathrm{A} 7 & \phi \mathrm{A} 5 & \phi \mathrm{A} 6 & \phi \mathrm{A} 1\end{array}$

$+\quad+\quad+\quad+\quad+\quad++$

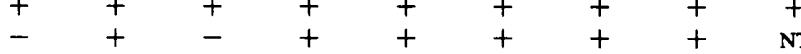

$\begin{array}{lllllll}- & - & + & + & - & + & -\end{array}$

$+\quad+\quad+\quad+\quad-\quad-\quad+$

$-++\ldots+\infty \quad+\quad+\quad+$

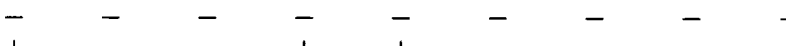

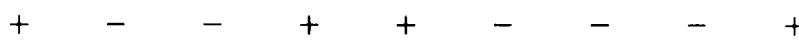

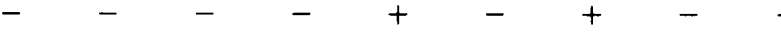

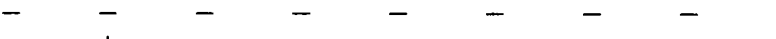

$\begin{array}{lllllll}- & + & - & - & - & - & -\end{array}$

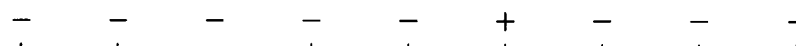

$+\quad+\quad+\quad+\quad+\quad+\quad+\quad+$

$+-\quad-\quad+\quad+\quad+\quad-\quad+\quad+$

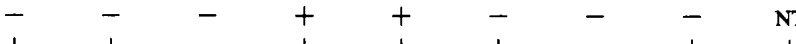

$+\quad+\quad+\quad+\quad+\quad-\quad+$

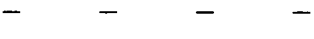

$-$

$-\quad-\quad-$

$-\quad-\quad-$

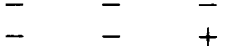

$-\quad-\quad-$

$-\quad-\quad-$

$-\quad-\quad-$

$-\quad-\quad-$

$-\quad-\quad+$

$-\quad-\quad+$

$+\quad+\quad+$

$+\quad+\quad+$

NT, Not tested; + , plaque formation (variations occurred in both e.o.p. values and size of the plaques, data not shown); - , e.o.p. $<10^{-5}$, assuming an e.o.p. of 1 on S. antibioticus ATCC 11891.

* ATCC, American Type Culture Collection; CECT, Colección Española de Cultivos Tipo; CMI, Commonwealth Mycological Institute; ETHZ, Institutes der Eidgenössischen Technischen Hochschule Zürich; IMET, Institut für Mikrobiologie und Experimentelle Therapie, Jena; JII, John Innes Institute; KCC, Kaken Culture Collection; NRRL, Northern Regional Research Laboratories; UC, Upjohn Company; Z, Shionogi and Co.

$\dagger$ Leyh-Bouille et al. (1970).

This mechanism gives rise to phage genomes which are partially circularly permuted and terminally redundant. Actinophages with this type of organization have already been reported (Chung, 1982; Sladkova, 1982; Grund \& Hutchinson, 1987) and $\phi A 5$ and $\phi$ A6 could be new examples. The structure of the genome of $\phi \mathrm{Al}$ remains unknown but it does not seem to correspond to any of the cited models; sub-stoichiometric bands were not detected after electrophoresis of digested DNA and cohesive ends were not demonstrated.

\section{Genetic interrelation among phages}

Possible homology between the genomes of the different phages was investigated by Southern hybridizations. DNA from the nine newly isolated phages and also from $\phi \mathrm{C} 31$ and $\mathrm{SH} 10$, digested with appropriate restriction enzymes (Fig. $3 a$ ), was hybridized to $\phi \mathrm{A} 4, \phi \mathrm{A} 5, \phi \mathrm{A} 7$ and $\phi \mathrm{A} 8$ DNA, used independently as radioactive probes (Fig. $3 b, c, d, e$ ).

$\phi$ A4 DNA gave a strong hybridization signal with nearly all EcoRI-generated fragments of 
Table 4. Efficiency of plating of the phages on several endonuclease-producing strains

\begin{tabular}{|c|c|c|c|c|c|c|c|c|c|c|}
\hline \multirow[b]{2}{*}{ Strain } & \multirow{2}{*}{$\begin{array}{l}\text { Enzyme } \\
\text { produced }\end{array}$} & \multicolumn{9}{|c|}{ Efficiency of plating* } \\
\hline & & $\phi \mathrm{A} 2$ & $\phi \mathrm{A} 4$ & $\phi \mathrm{A} 9$ & $\phi \mathrm{A} 3$ & $\phi \mathrm{A} 8$ & $\phi \mathrm{A} 7$ & $\phi \mathrm{A} 5$ & $\phi \mathrm{A} 6$ & $\phi \mathrm{Al}$ \\
\hline $\begin{array}{l}\text { S. albus } \mathrm{G} \\
\text { S. albus } \mathrm{J} 1074\end{array}$ & SalGI & $\begin{array}{r}<10^{-5} \\
10^{-1}\end{array}$ & $\begin{array}{r}<10^{-5} \\
10^{-1}\end{array}$ & $\begin{array}{l}<10^{-7} \\
<10^{-7}\end{array}$ & $\begin{array}{c}<10^{-5} \\
6\end{array}$ & $\begin{array}{c}<10^{-5} \\
1\end{array}$ & $\begin{array}{l}5 \\
7\end{array}$ & $\begin{array}{r}<10^{-5} \\
10^{-3}\end{array}$ & $\begin{array}{r}<10^{-6} \\
5 \times 10^{-2}\end{array}$ & $\begin{array}{c}<10^{-4} \\
1\end{array}$ \\
\hline $\begin{array}{l}S \text { albus } \mathrm{P} \\
S \text {. achromogenes }\end{array}$ & SalPI & $10^{-1}$ & $<10^{-5}$ & $<10^{-6}$ & 1 & 2 & 4 & $<10^{-5}$ & $10^{-1}$ & 10 \\
\hline ATCC 12767 & $\begin{array}{l}\text { SacI } \\
\text { SacII } \\
\text { SacIII }\end{array}$ & $<10^{-7}$ & $6 \times 10^{-1}$ & $<10^{-6}$ & $<10^{-5}$ & $<10^{-5}$ & $<10^{-7}$ & $<10^{-5}$ & $<10^{-6}$ & $<10^{-4}$ \\
\hline $\begin{array}{r}\text { S. liv } \\
132\end{array}$ & & $<10^{-4}$ & $<10^{-4}$ & $<10^{-5}$ & $<10^{-4}$ & $<10^{-4}$ & $<10^{-4}$ & $<10^{-4}$ & $<10^{-4}$ & $<10^{-4}$ \\
\hline
\end{tabular}

* The e.o.p. was calculated with respect to plating efficiency on S. antibioticus ATCC 11891 .

$\phi$ A9 DNA and a very weak signal with two fragments of $\phi$ A2 DNA digested with the same enzyme (Fig. $3 b$ ). $\phi$ A5 DNA strongly hybridized with all EcoRV-generated fragments of $\phi A 6$ DNA and more weakly with some fragments of $\phi$ A8 DNA digested with $B g l \mathrm{II}$; very faint bands were observed in lanes corresponding to $\phi \mathrm{A} 3$ and SH10 DNAs respectively digested with $E c o$ RI and $B g l \mathrm{II}$ (Fig. $3 c$ ). $\phi$ A8 DNA showed strong homology with all the fragments of $\phi \mathrm{A} 3$ and SH10 DNAs, digested with $E c o$ RI and $B g l$ II respectively (Fig. $3 e$ ). In our experimental conditions $\phi$ A7 DNA did not hybridize with the DNA of any of the other phages used in these experiments (Fig. $3 d$ ). None of the four phage genomes used as probe hybridized with $\phi A 1$ or $\phi \mathrm{C} 31$ DNA.

The results from the Southern hybridization experiments, together with the characteristics of the phages reported above (Tables 1 and 2, Fig. 1), allowed their classification into five groups: (I) $\phi \mathrm{A} 2, \phi \mathrm{A} 4$ and $\phi \mathrm{A} 9$, (II) $\phi \mathrm{A} 3$ and $\phi \mathrm{A} 8$, (III) $\phi \mathrm{A} 7$ (phages belonging to these three groups having linear double-stranded DNA molecules with cohesive ends), (IV) $\phi$ A5 and $\phi \mathrm{A} 6$ (possibly $h^{\circ}$ ving terminally redundant and partially permuted genomes) and (V) $\phi \mathrm{Al}$ ( which appears to be very different from all the other phages with respect to both the size and structure of its genome and the dimensions of its phage particle). Despite differences in genome structure, phages in groups II and IV are genetically related, since $\phi$ A5 DNA of group IV hybridized, albeit weakly, with DNA of phages in group II.

\section{Host-range and interaction with host-specified restriction-modification systems}

The host-range of the phages was examined by plaque formation on 31 strains of Streptomyces, belonging to 16 species. Each phage displayed a different host-range (Table 3), which varied from relatively narrow, as in the case of $\phi A 9$ ( 7 out of the 31 strains positive), to relatively broad, as in $\phi \mathrm{A} 3$ and $\phi \mathrm{A} 8$ (19 out of 31 strains positive). In addition to $S$. antibioticus ATCC 11891, the host in which the phages were originally isolated, all the phages formed plaques on $S$. showdoensis and $S$. scabies, an observation which could have taxonomic implications.

None of the nine phages was able to infect strains of the actinomycete genera Micromonospora, Nocardia and Saccharopolyspora. This could reflect the absence of receptors for Streptomyces phages in actinomycetes with different cell wall types. Thus, while Streptomyces has a type I cell wall composition, Micromonospora has type II and both Nocardia and Saccharopolyspora have type IV (Lechevalier \& Lechevalier, 1981; Labeda, 1987). Failure to infect genera with different cell wall composition might be a general feature of actinophages, as has already been reported (Grund \& Hutchinson, 1987; McHenney \& Baltz, 1988).

The plating efficiencies of the nine phages were tested on three strains of Streptomyces known to produce type II restriction endonucleases ( $S$. albus $\mathrm{G}, S$. albus $\mathrm{P}$ and $S$. achromogenes), on a restrictionless mutant of $S$. albus G (S. albus J1074; Chater \& Wilde, 1980), and on S. lividans 1326, a strain which seems to lack any restriction activity (Table 4). The numbers of 
recognition sites in each of the phages for the relevant restriction enzymes are shown in Table 2.

The presence of Sal GI sites in a given phage genome correlated with an inability of the phage to form plaques on $S$. albus G, the strain which produces the SalGI restriction endonuclease (Arrand et al., 1978). Thus, only $\phi \mathrm{A} 7$, which contains no restriction sites for SalGI, gave plaques on $S$. albus G. $\phi \mathrm{A} 1, \phi \mathrm{A} 3$ and $\phi \mathrm{A} 8$, although unable to infect the wild-type strain, plated with high efficiency on the restrictionless mutant $S$. albus J1074, demonstrating that the restriction enzyme was the only barrier preventing development of these phages on $S$. albus $\mathrm{G}$. This result corroborates the important role of $S a l$ GI endonuclease in protecting the host against phage infection, as was originally reported by Chater \& Wilde (1976). Other phages either gave no plaques ( $\phi \mathrm{A} 9)$ or formed very small plaques with low efficiency of plating $(\phi \mathrm{A} 2, \phi \mathrm{A} 4, \phi \mathrm{A} 5$ and $\phi \mathrm{A} 6)$ on $S$. albus $\mathrm{J} 1074$, indicating that factor(s) other than restriction by SalGI endonuclease could prevent infection of $S$. albus $\mathrm{G}$ by actinophages.

Among the six phages which lacked Pst I sites in their DNA ( $\phi \mathrm{Al}, \phi \mathrm{A} 3, \phi \mathrm{A} 5, \phi \mathrm{A} 6, \phi \mathrm{A} 7$ and $\phi \mathrm{A} 8$ ) only $\phi \mathrm{A} 5$ was unable to infect $S$. albus $\mathrm{P}$, producer of the restriction enzyme $S a l \mathrm{PI}$, which is an isoschizomer of PstI (Chater, 1977, 1980). $\phi$ A4 and $\phi A 9$, two of the three phages with many Pst I sites in their genome, gave no plaques on $S$. albus $\mathrm{P}$ and therefore, as in the case of $S a l G I$, a correlation was found between the reduction in plating efficiency and the presence of restriction enzyme recognition sites. However, since restrictionless mutants of $S$. albus $\mathrm{P}$ are not available, the possibility could not be ruled out that factor(s) other than restriction are responsible for reduced plating efficiency on $S$. albus $\mathrm{P}$ by phages with PstI sites. $\phi$ A2, a third phage also containing many PstI sites in its DNA, could infect $S$. albus $\mathrm{P}$ with relatively high efficiency of plating $\left(10^{-1}\right)$, but with very small plaques.

S. achromogenes ATCC 12767 produces at least three type II restriction endonucleases (J. R. Arrand, P. A. Myers \& R. J. Roberts, unpublished observations, cited by Roberts, 1987): SacI, SacII (commercially available) and SacIII. All the phages except $\phi \mathrm{A} 1$ had SacI and/or SacII recognition sites in their DNA, and all except $\phi A 4$ were unable to infect this strain. Surprisingly $\phi A 4$, which has many SacI and SacII sites in its DNA, gave normal-sized plaques, with an efficiency of plating close to 1 on $S$. achromogenes. Mechanism(s) used by $\phi$ A4 to avoid restriction by the $S a c$ enzymes and by $\phi \mathrm{A} 2$ to escape the SalPI enzyme are currently under study.

None of the phages was able to form plaques on $S$. lividans 1326 , despite the fact that no restriction endonucleases have been detected in this strain. In the cases of phages $\phi \mathrm{A} 5, \phi \mathrm{A} 7$ and $\phi A 8$ at least, adsorption specificity was the barrier preventing infection of this host. This was demonstrated by adsorption experiments and also by transfection of $S$. lividans protoplasts with DNA of these phages, using S. antibioticus ATCC 11891 as indicator strain (L. A. Diaz \& M. R. Rodicio, unpublished). The inability of $\phi \mathrm{A} 5$ to form plaques on $S$. albus $\mathrm{P}$, despite the absence in its genome of recognition sites for the enzyme produced by the host, could be also due to an inability to adsorb to this strain.

\section{Identification of temperate phages}

Seven of the nine phages isolated from soil on $S$. antibioticus ATCC 11891 formed turbid plaques in this host. However, cells growing within the plaques did not release phages and they were not immune to superinfection. Therefore none of the phages appeared to produce stable lysogenic derivatives in their original host.

The temperate character of the nine phages was tested in other Streptomyces strains in which they produced turbid plaques. At least three phages $(\phi \mathrm{A} 5, \phi \mathrm{A} 7$ and $\phi \mathrm{A} 8)$ formed stable lysogens in some of the strains tested, as judged by the liberation of free phages by spontaneous induction and by immunity to superinfection. Thus $\phi \mathrm{A} 5$ was temperate in $S$. antibioticus KCC S-0707, $\phi \mathrm{A} 8$ in $S$. antibioticus KCC S-0707 and $S$. orchidaceus NRRL B-2454 and $\phi \mathrm{A} 7$ in $S$. albus $\mathrm{P}, S$. albus J1074, S. orchidaceus NRRL B-2454 and in three strains of $S$. lavendulae (NRRL B-1871, NRRL B-2036 and NRRL B-2343). Since $\phi A 5, \phi A 7$ and $\phi A 8$ contain all the genetic information required for the establishment and maintenance of lysogeny, failure to lysogenize $S$. antibioticus ATCC 11891 could be due to absence of an attB integration site in this host.

Phages $\phi \mathrm{A} 5, \phi \mathrm{A} 7, \phi \mathrm{A} 8$ and also $\phi \mathrm{C} 31$ belong to different immunity groups, since each was 
able to lyse strains which were lysogenic for the others. SH10 and R4, two phages which are in the same immunity group (Chater, 1986) were unable to infect $\phi \mathrm{A} 8$ lysogens.

From the results reported in this paper it would appear that $\phi \mathrm{A} 7$ and $\phi \mathrm{A} 8$ are good candidates for the development of cloning vectors: (i) they are temperate, a characteristic which would allow selection of cloned genes during the phage lysogenic cycle, (ii) they have cohesive ends, offering the possibility of isolating deletion mutants among phages resistant to treatment with chelating agents, and (iii) they have a relatively wide host-range, respectively infecting 18 and 19 out of 31 Streptomyces strains tested. If the failure of these phages to lysogenize $S$. antibioticus ATCC 11891 is due to the absence of an $a t t B$ site, prophage formation could be achieved by the insertion of a fragment of host DNA into the phage genome, thereby conferring the homology required for integration.

The authors are grateful to Dr K. F. Chater for critical reading of this manuscript. L. A.D. was the recipient of a grant from the Plan de Formación del Personal Investigador of the Ministerio de Educación y Ciencia (Spain). This work was supported by grant PB85-0403 from the CAICYT (Spain).

\section{REFERENCES}

Arrand, J. R., Myers, P. A. \& Roberts, R. J. (1978). A new restriction endonuclease from Streptomyces albus G. Journal of Molecular Biology 118, 127-135.

Botstein, D., Waddell, C. H. \& King, J. (1973). Mechanism of head assembly and DNA encapsulation in Salmonella phage P22. I. Genes, proteins, structure and DNA maturation. Journal of Molecular Biology 80, 669-695.

Bradley, S. R., Anderson, D. L. \& Jones, L. A. (1961). Phylogeny of actinomycetes as revealed by susceptibility to actinophage. Developments in Industrial Microbiology 2, 223-237.

ChATER, K. F. (1977). A site-specific endodeoxyribonuclease from Streptomyces albus CMI 52766 sharing site-specificity with Providencia stuartii endonuclease PstI. Nucleic Acids Research 4, 1989-1998.

ChATER, K. F. (1980). A comparison of DNA cleavage by the restriction enzymes SalPI and PstI. Nucleic Acids Research 8, 4943-4954.

CHATER, K. F. (1986). Streptomyces phages and their applications to Streptomyces genetics. In The Bacteria: a Treatise on Structure and Function, vol. IX, Antibiotic-producing Streptomyces, pp. 119-158. Edited by S. W. Queener \& L. E. Day. New York: Academic Press.

Chater, K. F. \& Carter, A. T. (1979). A new wide host-range temperate bacteriophage, R4, of Streptomyces and its interaction with some restrictionmodification systems. Journal of General Microbiology 115, 431-442.

Chater, K. F. \& WiLDE, L. C. (1976). Restriction of a bacteriophage of Streptomyces albus G involving endonuclease SalI. Journal of Bacteriology 128, 644-650.

Chater, K. F. \& Wilde, L. C. (1980). Streptomyces albus $\mathrm{G}$ mutants defective in the $\mathrm{SalGI}$ restrictionmodification system. Journal of General Microbiology 116, 323-334.

Chater, K. F., King, A. A., Rodicio, M. R., Bruton, C. J., Fisher, S. H., Piret, J. M., Smith, C. P. \& Foster, S. G. (1985). The cloning and analysis of Streptomyces DNA in $\phi \mathrm{C} 31$-derived vectors. In Microbiology - 1985, pp. 421-426. Edited by L. Leive. Washington DC: American Society for Microbiology.
CHUNG, S. T. (1982). Isolation and characterization of Streptomyces fradiae plasmids which are prophage of the actinophage $\phi \mathrm{SF} 1$. Gene 17, 239-246.

DowDING, J. E. (1973). Characterization of a bacteriophage virulent for Streptomyces coelicolor A3(2). Journal of General Microbiology 76, 163-176.

FoOR, F., Roberts, G. P., Morin, N., SNyder, L., Hwang, M., Gibbons, P. H., Paradiso, M. J., Stotish, R. L., Ruby, C. L., Wolanski, B. \& STREICHER, S. L. (1985). Isolation and characterization of the Streptomyces cattleya temperate phage TG1. Gene 39, 11-16.

Grund, A. D. \& Hutchinson, C. R. (1987). Bacteriophages of Saccharopolyspora erythraea. Journal of Bacteriology 169, 3013-3022.

Hardisson, C., Manzanal, M. B., Salas, J. A. \& SuAREZ, J. E. (1978). Fine structure, physiology and biochemistry of arthrospore germination in Streptomyces antibioticus. Journal of General Microbiology 105, 203-214.

Harris, J. E., Chater, K. F., Bruton, C. J. \& Piret, J. M. (1983). The restriction mapping of $c$ gene deletions in Streptomyces bacteriophage $\phi \mathrm{C} 31$ and their use in cloning vector development. Gene 22 , 167-174.

Hopwood, D. A., BibB, M. J., Chater, K. F., Kieser, T., Bruton, C. J., Kieser, J. M., Lydiate, D. J., SMith, C. P., WARD, J. M. \& SChrempF, H. (1985). Genetic Manipulation of Streptomyces. A Laboratory Manual. Norwich: The John Innes Foundation.

JACKSON, E. N., JACKsON, D. A. \& DoANS, R. J. (1978). EcoRI analysis of bacteriophage P22 DNA packaging. Journal of Molecular Biology 113, 365-388.

Klaus, S., Krugel, H., Suss, F., Neigenfind, M., ZimmermanN, J. \& Taubeneck, U. (1981). Properties of the temperate actinophage SH10. Journal of General Microbiology 123, 269-279.

KorN, F., WEINGARTNER, B. \& KUTZNER, H. J. (1978). A study of twenty actinophages: morphology, serological relationship and host range. In Genetic of Actinomycetales (Proceedings of the Forschungsinstitut Borstel), pp. 251-270. Edited by E. Freerksen, I. Tárnok \& J. H. Thumin. Stuttgart: G. Fisher Verlag.

LABEDA, D. P. (1987). Transfer of the type strain 
Streptomyces erythraeus (Waksman 1923) Waksman and Henrici 1948 to the genus Saccharopolyspora Lacey and Goodfellow 1975 as Saccharopolyspora erythraea sp. nov., and designation of a neotype strain for Streptomyces erythraeus. International Journal of Systematic Bacteriology 37, 19-22.

LeChevalier, H. A. \& Lechevalier, M. P. (1981). Introduction to the order Actinomycetales. In The Prokaryotes. A Handbook on Habitats, Isolation and Identification of Bacteria, vol. II, pp. 1915-1922. Edited by M. P. Starr, H. Stolp, H. G. Trüper, A. Balows \& H. G. Schlegel. Berlin: Springer-Verlag.

Leyh-Bouille, M., Bonaly, R., Ghuysen, J. M., TINELLI, R. \& TIPPER, D. (1970). LL-Diaminopimelic acid containing peptidoglycans in walls of Streptomyces sp. and of Clostridium perfringens (type A). Biochemistry 9, 2944-2952.

Lomovskaya, N. D., Chater, K. F. \& Mkrtumian, N. M. (1980). Genetics and molecular biology of Streptomyces bacteriophages. Microbiological Reviews 44, 206-229.

Lomovskaya, N. D., Mkrtumian, N. M., GostimsKAYA, N. L. \& DANILENKo, V. N. (1972). Characterization of temperate actinophage $\phi \mathrm{C} 31$ isolated from Streptomyces coelicolor A3(2). Journal of Virology 9, 258-262.

McHenney, M. A. \& Baltz, R. H. (1988). Transduction of plasmid DNA in Streptomyces spp. and related genera by bacteriophage FP43. Journal of Bacteriology 170, 2276-2282.

Morino, T., Isogal, T., KoJima, H., Takahashi, H. \&
SAITO, H. (1983). Cleavage analysis of actinophage R4 and its deletion mutants. Agricultural and Biological Chemistry 47, 1873-1878.

ROBERTS, R. J. (1987). Restriction enzymes and their isoschizomers. Nucleic Acids Research 15, r189r217.

Sladkova, J. A. (1982). Circular permutations of DNA molecules of Streptomyces griseus K5 actinophage Pg2. Molecular Biology (USSR) 16, 98-103.

STERnBERG, N. \& HoESS, R. (1983). The molecular genetics of bacteriophage P1. Annual Review of Genetics 17, 123-158.

SuÁrez, J. E. \& Chater, K. F. (1981). Development of a DNA cloning system in Streptomyces using phage vectors. Ciencia biologica 6, 90-110.

Suárez, J. E., Caso, J. L., Rodríguez, A. \& HARDisSON, C. (1984). Structural characteristics of the Streptomyces bacteriophage $\phi$ C 31 . FEMS Microbiology Letters 22, 113-117.

Thompson, C. J., WARD, J. M. \& Hopwood, D. A. (1980). DNA cloning in Streptomyces: resistance genes from antibiotic-producing species. Nature, London 286, 525-527.

Voeykova, J. A., Slavinskaya, E. V., Orekhov, A. V. \& LomovskAYA, N. D. (1979). Identification of restriction and modification systems in Streptomyces strains. Genetika 15, 1746-1756.

Walter, F., Hartmann, M. \& Klaus, S. (1981). Restriction endonuclease analysis of DNA from the Streptomyces phages SH3, SH5, SH10 and SH13. Gene 13, 57-63. 